\title{
HET PIJNLIJK WOORD
}

\author{
DOOR
}

G. J. STAAL

In een artikel in het Haagsch Maandblad van November 1927, getiteld „Suriname als Reclasseeringsland”, schreef Mr. Dr. van den Helm iets over de lotgevallen van een déporté uit Fransch Guyana en voegde daaraan toe: „Ik vermeld deze bijzonderheden om te laten zien voor welke vergrijpen Frankrijk zijn zonen naar het bagno zendt".

Die woorden riepen herinneringen in mij op aan de ongelukkigen, die door den rechter uit hun land uitgewezen, gedoemd worden hun schuld te boeten in levenslange verbanning naar Cayenne en bij honderden het leven wagen op zee en in de bosschen om ergens vrijheid en een bestaan te vinden.

Als Gouverneur kreeg ik geregeld van het Bestuur van Cayenne de stamboeken (feuilles) toegezonden van alle gedeporteerden, die uit de strafétablissementen ontvlucht waren, een beleefde waarschuwing voor het geval, dat de gesignaleerden op Suriname's gebied mochten worden aangetroffen. De feuilles hadden kolommen, waarvan een de verschillende ondergane straffen vermeldde. Daarin reeds lag een heel stuk levensgeschiedenis, voorafgegaan aan de verbanning. In den regel was het een lange rij van kleine veroordeelingen, veelal afwisselend wegens landlooperij en oplichting, en vaak eindigend met het beslissend vonnis „pour avoir exercé la profession de souteneur".

Maar het was niet die kolom, die het meest mijne aandacht boeide en mij het geleide leven het scherpst en schrijnendst afteekende. Dat deed de eerste, die den persoon beschreef.

Dàar las ik het: eerst den naam, dan de voornamen, jaar en dag van geboorte, en daaronder kwam het, - hoe dikwijls! - achter het gedrukte „Père”, het geschreven woord, dat zòoveel onthulde, zòoveel verklaarde: Inconnu ! 